\title{
THIRD INTERNATIONAL CONFERENCE ON ENVIRONMENTAL FUTURE: MAINTENANCE OF THE BIOSPHERE
}

Co-sponsored by the Foundation for Environmental Conservation and the University of Edinburgh, and held at the latter during 24-26 September 1987

PROGRAMME*

Thursday $\quad 18.30-22.30 \mathrm{hrs}$ : Secretary-General and Mrs Nicholas Polunin 'at home' for get-together drinks and Buffet Supper for 24 September participants and their spouses and guests in the Overseas League Headquarters, 100 Princes Street (opposite Edinburgh Castle).

Conference Room of the University Library, George Square, Edinburgh, Scotland

Friday 25 September

09.00 Announcements, Messages, and Confirmation and Briefing of the Resolutions Committee: Secretary-General \& Editor of the ICEFs

09.15 Session 1. The Global System of Nature and the World Stage of Man

a) Evolution of The Biosphere and the Ascent of Industrial Man: Prof. Sir John Burnett (UK)

b) The World Stage of Modern Man: Need for Diversity and Stability: Prof. José I. Furtado (Malaysia \& UK)

Chairman: Prof. Sir David Smith

Panellists: $\quad$ Dr Maung Nay Htun (Burma \& Thailand), H.E. Raynell A. Chuk (Canada \& Kenya), Dr G.M. Oza (India).

10.45 Coffee

11.00 Session 2. The Biosphere in Transition

a) The Sources of Change: H.E. Prof. Olav Gjaerevoll (Norway)

b) Their Effects and Interactions: Dr Michael D. Gwynne (UK \& Kenya)

Chairman: Dr Thomas F. Malone (USA)

Panellists: $\quad$ Prof. Reid A. Bryson (USA), Prof. Elisabeth Mann Borgese or Dr. Christine Furedy (Canada),

12.45 Lunch in the Library

Dr Genady N. Golubev (USSR \& Kenya).

14.00 Session 3. Global Priorities

a) Sustaining Basic Physico-chemical and Climatic Systems: Prof. Michael McElroy (USA)

b) Maintaining Ecological Productivity and Genetic Diversity: Prof. Ellis B. Cowling (USA) \& Prof. Fred T. Last (UK)

Chairman: Dr George M. Woodwell or Prof. Craig B. Davis (USA)

Panellists: $\quad$ Prof. Terence A. Mansfield or Dr Carole E. Pitcairn (UK), Prof. Richard E. Schultes (USA), Dr William D. Clark (USA \& Austria).

15.30 Tea

15.45 Session 4. The Attainable Ideal in Human and Ecological Terms

a) Moral Thrusts: Prof. Lynton Keith Caldwell (USA)

b) Biological Realities: Dr Arthur H. Westing (USA \& Sweden)

Chairman: Prof. Aubrey W.G. Manning (UK)

Panellists: $\quad$ Philip J. Stewart (UK), Dr Bent E. Juel-Jensen (Denmark \& UK), Dr Eddie K.S. Hum (Singapore \& Thailand).

17.30 Break and procession to the Lecture Hall, David Hume Tower, George Square, Edinburgh.

18.00 Baer-Huxley Memorial Lecture: 'Our Menaced World': Mrs Gro Harlem Brundtland, Prime Minister of Norway and Chairman of the World Commission on Environment \& Development - the Lecture being delivered by her or by the Norwegian Ambassador to the United Nations in Geneva, H.E. Martin Huslid.

Chairman: Nicholas Polunin

It is hoped that some time will be available for open discussion.

19.30 Reception in the Old College, University of Edinburgh.

20.15 Conference Dinner in the University Senate House, Old College, Edinburgh.

Saturday 26 September

\subsection{Session 5. Practical Targets for Sustainability and Development}

Single topic addressed by one keynote speaker (Dr Martin W. Holdgate, Deputy Secretary \& Chief Environmental Scientist, UK Department of the Environment), followed by panellists from each of the six inhabited continents as follows: Prof. J. Gordon Nelson (Canada, speaking for North America): H.E. Prof. Paulo Nogueira-Neto or Prof. José Lutzenberger (Brazil, speaking for South America); Prof. Ma Shijun (China, speaking for Asia); Dr Donald F. McMichael (Australia, speaking for Australasia); Prof. David P.S. Wasawo or Dr Perez M. Olindo (Kenya, speaking for Africa); and Dr Werner Stumm (Switzerland, speaking for Europe).

Chairman: Prof. Donald J. Kuenen (Netherlands).

11.30 Coffee

12.00 Public Meeting in David Hume Tower, George Square, Edinburgh, under the Chairmanship of Sir John Burnett, Principal \& Vice-Chancellor of the University of Edinburgh - to debate the conclusions of the Conference and, it is hoped, to adopt an 'Edinburgh Imperative on Maintaining The Biosphere' as a fitting conclusion to the formal proceedings.

13.15 Subscription Luncheon [to meet Participants and Press]

* The language of the Conference will be English. Each session will normally commence with its Chairman's introduction (at most 5 minutes), followed by a 12-15 minutes' résumé of each of the keynote papers (circulated previously) and then 4-6 minutes' commentary by each panellist. With strict chairmanship this should allow plentiful time for open discussion by the above-named and rather numerous other invited participants, the whole being recorded for expected publication after due editing as on previous occasions. It is hoped to stage a small exhibition of Scottish art and to hear some bagpipes. Titles of papers will not necessarily be those given above.

Co-organizer:

Dr Ulrich E. LoENING, Director

Centre for Human Ecology

University of Edinburgh

15 Buccleuch Place

Edinburgh EH8 9LN

Scotland, UK
Secretary-General \& Editor:

Prof. Nicholas Polunin, DPhil. DSc, CBE

7 Chemin Taverney

1218 Grand-Saconnex

Geneva, Switzerland

Tel. (022) $982383 / 4$

[During 22-28 September at

100 Princes Street, Edinburgh EH2 3AA, Scotland, UK. Tel. (031) 225 1501] 